\section{Pharmacokinetics of lidocaine in children with congenital heart disease}

Frederick A. Burrows MD FRCPC, Jerrold Lerman MD FRCPC, Kenneth M. LeDez MD, H. Andrew Strong PhD
The purpose of this study was to determine the pharmacokinetics of lidocaine in children with congenital heart disease (CHD). Fifteen children with left to right intracardiac shumting of blood (acyanotic group) and 15 children with right to left intracardiac shunting of blood (cyanotic group) were studied and compared with 15 children without CHD (control group). Lidocaine (1.5 $m \mathrm{~g} \cdot \mathrm{kg}^{-1}$ ) was injected into a peripheral vein over $30 \mathrm{sec}$ and serial samples of arterial blood were oblained up $10120 \mathrm{~min}$ after completion of the infusion. Total and free lidocaine were analyzed by enzyme inmunoassy. The serum concentration of alpha,-acid glycoprotein $\left(\alpha_{1}-A G P\right)$ at induction of anaesthesia was measured in the three groups by radial immunodiffusion. The percent free lidocaine $(100 \times$ Ufree lidocaine] / ltotal lidocainel) was greater at $30 \mathrm{sec}$ post-infusion in all three groups (35-37\%) than it was at any other time but was not significantly different among the three groups $(P<0.05)$. There was no significant difference in either the percent free or the total lidocaine concentration at any sample time or in any of the pharmacokinetic variables among the three groups. The serum concentration of $\alpha_{1}$-AGP did not differ significantly among the three groups of patients. We conclude that the presence of intracardiac shunts does not alter the pharmacokinetic behaviour of intravenous lidocaine $\left(1.5 \mathrm{mg} \cdot \mathrm{kg}^{-1}\right)$ in children. The

\section{Key words}

ANAESTHESIA: paediatrics;

ANAESTHETICS, LOCAL: lidocaine;

HEART: congenital defects;

PHARMACOKINETICS: lidocaine.

From the Departments of Anaesthesia and Clinical Pharmacology, and the Research Institute, The Hospital for Sick Children, University of Toronto, Toronto, Ontario, Canada. Supported with a grant from the Physicians' Services Incorporated, Toronto, Ontario, Canada. Presented in part at the Annual Meeting of the American Society of Anesthesiologists, Las Vegas, Nevada, October 1987.

Address correspondence 1o: Dr. Frederick A. Burrows, Department of Anaesthesia, The Hospital for Sick Children, 555 University Avenue, Toronto, Ontario, Canada M5G IX8. Accepted for publication 10th October, 1990. percent free lidocaine is greatest immediately post-injection and this may mitigate against rapid bolus administration of intra. venous lidocaine in children.

Le but de l'étude érait de déterminer la pharmacocinétique de la lidocaïne chez les enfants atteints de maladie cardiaque congénitale (CHD). Quinze enfants ayant un shumt intracardiaque gauche-droit (groupe acyanotique) et quinze enfants avec un shunt intracardiaque droit-gauche (groupe cyanotique) ont été étudiés et comparés avec 15 enfants sans CHO (groupe contrôle). La lidocaïne $\left(1,5 \mathrm{mg} \cdot \mathrm{kg}^{-1}\right)$ a été injectée dans une veine périphérique en $30 \mathrm{sec}$. et des échantillons sériés de sang artériel furant obtenus jusqu'à $120 \mathrm{~min}$. après la fin de la perfusion. La lidocaïne totale et libre furent analysées par immunoessai. La concentration sérique de l'acide alpha, glycoprotéine $\left(\alpha_{1}-A G P\right)$ à l'induction de l'anesthésie fut mesurée dans les trois groupes par immunodiffusion. Le pourcentage de lidocaine libre (100 $\times$ /lidocaine / / lidocaine totale) ) fut plus grand à 30 sec après la perfusion dans les trois groupes (35$37 \%$ ) qu'il n'était dans un aucun autre temps mais n'était pas significativement différent parmi les trois groupes $(P<0,05)$. Il $n^{\prime} y$ avait aucune différence significative dans soit le pourcentage de lidocaïne libre ou torale dans aucun des échamillons ni dans aucune des variables pharmacocinétiques parmi les trois groupes. Les concentrations sériques de $\alpha_{I}$-AGP ne différaient pas significativement parmi les trois groupes de patients. On conclut que la présence de shunt intracardiaque $n$ 'altère pas le comportement pharmacocinétique de la lidocaïne intraveineuse $\left(1,5 \mathrm{mg} \cdot \mathrm{kg}^{-1}\right)$ chéz les enfants. Le pourcentage de lidocaine libre était plus grand immédiatement après l'injection el ceci nous incite à ne pas administrer la lidocaïne par un bolus rapide par voie intraveineuse chez les enfants.

In patients without congenital heart disease (CHD) 60 $80 \%$ of an iv lidocaine bolus is absorbed by the lung on a first pass basis and is subsequently released with time. ${ }^{1-5}$ Patients with acyanotic CHD and left to right $(L \rightarrow R$ ) intracardiac shunting of blood with increased pulmonary blood flow demonstrate an abnormal circulation in that a proportion of the pulmonary venous blood returning to the heart does not pass directly to the systemic 
circulation but re-enters the pulmonary circulation allowing for further sequestration of lidocaine in the lung. In contrast, patients with cyanotic CHD due to right to left $(\mathrm{R} \rightarrow \mathrm{L})$ intracardiac shunting of blood demonstrate abnormal circulation in that systemic venous blood returning to the heart does not pass directly to the lungs but enters more directly into the systemic arterial circulation potentially allowing a higher arterial lidocaine concentration. ${ }^{6}$ These differences might be expected to delay the increase in arterial serum concentration of lidocaine in patients with acyanotic CHD and result in a more rapid onset and higher peak concentration of lidocaine in the patients with cyanotic CHD compared with those without CHD.

To investigate this hypothesis we studied the pharmacokinetics of total and free lidocaine in children with acyanotic and cyanotic CHD scheduled for elective cardiac surgery and compared the results with those from children without CHD, scheduled for elective surgery.

\section{Methods}

After approval by the Human Review Committee of The Hospital for Sick Children and written informed parental consent, 45 unpremedicated children (1-5 yr) ASA physical status I-III admitted for elective surgery were studied. Exclusion criteria included the concurrent treatment with cardiac medications and the presence of any of the factors known to affect the serum concentration of the lidocaine binding protein alpha $a_{1}$-acid glycoprotein $\left(\alpha_{1}\right.$ AGP) i.e., recent medications, surgery, infectious or inflammatory processes, neoplasm, organ dysfunction (e.g., renal), metabolic or endocrine disorders. Patients were divided into three groups according to cardiological diagnosis: (1) a control group with normal cardiac anatomy $(n=15),(2)$ an acyanotic group with increased pulmonary blood flow and $\mathrm{L} \rightarrow \mathrm{R}$ intracardiac shunting of blood ( $n=15$ ), and (3) a cyanotic group with decreased pulmonary blood flow and $R \rightarrow L$ intracardiac shunting of blood ( $n=15)$

The anaesthetic technique was standardized to control for anaesthetic effects on drug distribution. ${ }^{7}$ Anaesthesia was induced with thiopentone $5 \mathrm{mg} \cdot \mathrm{kg}^{-1}$, atropine 0.02 $\mathrm{mg} \cdot \mathrm{kg}^{-1}$ and pancuronium $0.15 \mathrm{mg} \cdot \mathrm{kg}^{-1}$. The tracheas were intubated and the lungs were mechanically ventilated to normocarbia $\left(\mathrm{PaCO}_{2}=32-38 \mathrm{mmHg}\right)$. Anaesthesia was maintained with a mixture of nitrous oxide and halothane in oxygen.

To determine the serum concentrations of $\alpha_{1}$-AGP, arterial blood $(1 \mathrm{ml})$ was obtained after induction of anaesthesia. The blood was stored in glass test tubes that were sealed with plastic film. The clotted blood samples were centrifuged within one hour of collection. The serum was pipetted into a second glass tube and this was sealed with plastic film and refrigerated at $-20^{\circ} \mathrm{C}$ until analysis.

The serum concentrations of $\alpha_{1}$-AGP were measured by radial immunodiffusion. ${ }^{8}$ Five $\mu$ l aliquots of serum were incubated for $72 \mathrm{hr}$ commercially prepared plates (Behring Inc.) containing rabbit antibodies to human $\alpha_{1}$-AGP. The diameter of the resultant precipitate was measured using an optical micrometer supplied by the assay manufacturer (Behring Inc.), and the serum concentration of $\alpha_{1}$-AGP was determined from standard tables. Each plate contained 12 wells: one or two wells were used to incubate the protein standard solutions, and the remainder for patient serum. All of the plates were manufactured from the same batch of antibodies. Protein standard solutions were used both as standards and to confurm the accuracy of the standard tables. The standards (90 $\mathrm{mg} \cdot \mathrm{dl}^{-1}$ ) were consistent throughout the study with a coefficient of variation $\leq 2 \%$. All assays were performed in duplicate and the mean values are reported. Because of the range of the serum concentrations of $\alpha_{1}$-AGP the relationship between the serum concentration of $\alpha_{1}$-AGP and the diameter of the precipitate was determined with the use of standard solutions between 4 and $90 \mathrm{mg} \cdot \mathrm{dl}^{-1}$ $\alpha_{1}$-AGP. The standard solutions were prepared by dilution of the standard supplied by Behring Inc. with bovine serum albumin $(5 \% \mathrm{wt} / \mathrm{vol})$. Each diluted standard was assayed in triplicate. The relationship between the concentration of $\alpha_{1}$-AGP and the diameter of the precipitate was linear $\left(r^{2}=0.98\right)$.

Lidocaine $\left(1.5 \mathrm{mg} \cdot \mathrm{kg}^{-1}\right)$ iv was administered to each patient over a 30 -sec interval. Arterial blood samples ( $2 \mathrm{ml}$ ) were obtained before and at $0.5,1,3,5,7,10,20$, 30,60 and $120 \mathrm{~min}$ after administration of lidocaine. To determine free and total lidocaine concentration the blood samples were allowed to clot in a sealed glass tube and were then centrifuged within $30 \mathrm{~min}$. A protein-free (or free) fraction of each sample was obtained by centrifuging a portion of the serum for $20 \mathrm{~min}$ at a centrifugal force of $1800 \mathrm{G}$ in an ultracentrifugation device (Centrifree ${ }^{(\pi \mathrm{T} T}$, Amicon Corporation, Danvers, Massachusetts). Previous studies documented the absence of $\alpha_{1}$-AGP binding to the device. The total serum and protein-free fractions were stored in sealed glass test tubes at $-20^{\circ} \mathrm{C}$ until analysis

Total and free lidocaine concentrations were determined using EMIT homogeneous enzyme immunoassay (Syva Corporation, Palo Alto, California). ${ }^{9}$ This equipment included a Stasar III spectrophotometer (Gilford Instruments), an EMIT clinical Processor CP 5000 (Syva Corporation), and an EMIT Autocarousel (Syva Corporation). A minor modification of the EMIT technique was used to measure all concentrations less than 1.5 $\mu \mathrm{g} \cdot \mathrm{ml}^{-1} \cdot{ }^{10}$ The reliable limit of detection (three times background) was $0.1 \mu \mathrm{g} \cdot \mathrm{ml}^{-1}$. The intra-assay coefficients of variation of a $1.0 \mu \mathrm{g} \cdot \mathrm{ml}^{-1}$ standard measured 
using the modified assay was $<5 \%(n=6)$ whereas the intra-assay variation was $7.7 \%(n=16)$.

All assays were performed in duplicate and the mean values are reported.

\section{Data analysis}

Statistical significance was determined using one-way analysis of variance and the Tukey test for multiple pairwise comparisons. ${ }^{11,12}$ Statistical significance was accepted as $P<0.05$.

Plasma concentrations of lidocaine were analyzed using both model-dependent and independent methods according to the equation:

$\mathrm{Cl}=\mathrm{Ae}^{-\alpha \cdot t}+\mathrm{Be}^{-\beta \cdot t}$

where $\mathrm{G} t$ is the concentration any any time $\mathrm{t}, \mathrm{A}$ and $\mathrm{B}$ are the intercept values for the fast and slow components of the concentration-time curve and $\alpha$ and $\beta$ are the fast and slow rate constants, respectively. A two-compartment open model with elimination from the central compartment fit the data best using a weighted $\left(1 \cdot \mathrm{Y}^{-2}\right)$ non-linear least squares regression program, ADAPT. ${ }^{13}$ The apparent volume of the central compartment ( $\mathrm{Vc}$ ), the volume of distribution at steady state (Vss) and the initial distribution and elimination half-lives ( $\varphi_{q} \alpha$ and $t_{i} \beta$ respectively) were derived according to standard equations. ${ }^{14}$ The area under the blood concentration $x$ time curve (AUC) was calculated by the trapezoidal method from time 0 to the last blood sample $(C x)$. The $A U C_{t-\infty}$ was calculated using $C x \cdot \beta^{-1}$. The total plasma systemic clearance $(\mathrm{Cl})$ of lidocaine was calculated using the equation:

$\mathrm{Cl}=$ Dose $\cdot \mathrm{AUC}_{0-\infty}{ }^{-1}$

\section{Results}

The demographic and $\alpha_{1}$-AGP data are presented in Table 1. There was no significant difference in age, weight, or $\alpha_{1}$-AGP concentration among the three groups. The mean

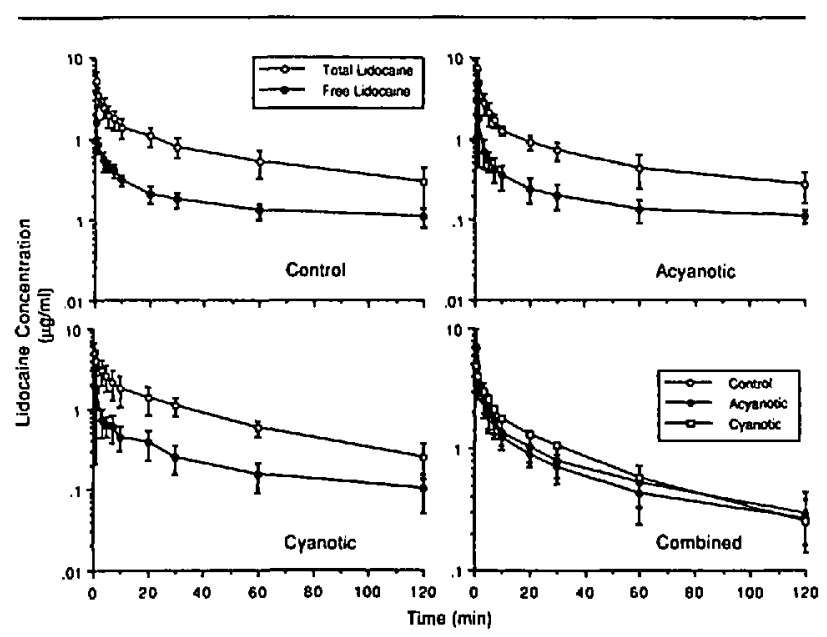

FIGURE Total and free lidocaine decay curves for the control, acyanotic and cyanotic groups of patients (mean \pm SD at each time point). The total lidocaine decay curves for the three groups are superimposed on the fourth decay plot. All patients received an iv infusion of lidocaine, $1.5 \mathrm{mg} \cdot \mathrm{kg}^{-1}$, over $30 \mathrm{sec}$.

haematocrit of the cyanotic group was significantly greater than the control and acyanotic groups. The pulmonary to systemic flow ratio was significantly greater in the acyanotic patients and significantly less in the cyanotic patients compared with the control patients.

Pharmacokinetic data calculated from the total serum lidocaine concentrations for the three groups are shown in Table II. The serum concentrations of lidocaine declined rapidly immediately after the $30 \mathrm{sec}$ infusion with an average $t_{2} \alpha$ of two to four minutes in all three groups. Within 10-20 min the serum concentrations of lidocaine declined more slowly in both groups (Figure). The mean $t_{2} \beta$ and the Vc did not differ significantly among the three treatment groups. The percent free lidocaine at 0.5 min was significantly greater than that at five min post-infusion and at all subsequent times but was not significantly different among the three groups. There

TABLE I Demographic and $\alpha_{1}$-acid glycoprotein data

\begin{tabular}{lccccc}
\hline & $\begin{array}{l}\text { Age } \\
(\mathrm{m} / \mathrm{h})\end{array}$ & $\begin{array}{l}\text { Weight } \\
(\mathrm{kg})\end{array}$ & $\begin{array}{l}\text { Haematocrit } \\
(\%)\end{array}$ & $\begin{array}{c}\alpha_{i} \cdot A G P \\
\left(\mathrm{mg} \cdot \mathrm{dl^{-1 }}\right)\end{array}$ & $\begin{array}{c}\boldsymbol{Q}_{p}: \dot{Q} s \\
(\text { ratio })\end{array}$ \\
\hline Control & 39.5 & 15.9 & 37.1 & 53.3 & $1: 1 \dagger$ \\
$(n=15)$ & \pm 10.7 & \pm 2.4 & \pm 3.4 & \pm 13.6 & \pm 0.0 \\
Acyanotic & 42.3 & 15.5 & 37.0 & 57.8 & $1.78: 1 \dagger$ \\
$(n=15)$ & \pm 22.6 & \pm 5.8 & \pm 2.1 & \pm 20.1 & \pm 0.62 \\
Cyanotic & 37.3 & 13.7 & $47.2^{*}$ & 62.9 & $0.61: 1 \dagger$ \\
$(n=15)$ & \pm 19.5 & \pm 4.6 & \pm 4.0 & \pm 13.7 & \pm 0.24 \\
\hline
\end{tabular}

Data are means \pm SD.

$* P<0.05$ compared with control and acyanotic patients.

$\dagger P<0.05$.

$\dot{\mathrm{Q}} \mathrm{p}: \dot{\mathrm{Q}} \mathrm{s}($ ratio) $=$ pulmonary to systemic flow ratio (control ratio was not measured but assumed to be $1: 1$ ). 
TABLE II Pharmacokinetic dala

\begin{tabular}{|c|c|c|c|c|c|c|c|c|c|c|c|}
\hline & $\begin{array}{l}f_{f} \alpha \\
(\min )\end{array}$ & $\begin{array}{l}I_{p} \beta \\
(m i i i)\end{array}$ & $\begin{array}{l}k_{2-1} \\
\left(\min ^{-1}\right)\end{array}$ & $\begin{array}{l}A \cup C_{0-\infty} \\
\left(\mu g \cdot m I^{-1}\right. \\
\left.m i n^{-1}\right)\end{array}$ & $\begin{array}{l}C l \\
(m) \cdot \min ^{-1} \\
\left.k g^{-1}\right)\end{array}$ & $\begin{array}{l}\text { Total } \\
\text { Lidocainet } \\
\left(\mu \mathrm{g} \cdot \mathrm{ml}^{-1}\right)\end{array}$ & $\begin{array}{l}\text { \% Free } \\
\text { Lidocainet }\end{array}$ & $\begin{array}{l}\text { Total } \\
\text { Lidocainet } \\
\left(\mu g \cdot \mathrm{m}^{-1}\right)\end{array}$ & $\begin{array}{l}\text { \% Free } \\
\text { Lidocainet }\end{array}$ & $\begin{array}{l}V c \\
\left(L \cdot k g^{-1}\right)\end{array}$ & $\begin{array}{l}V s s \\
\left(L \cdot k g^{-1}\right)\end{array}$ \\
\hline $\begin{array}{l}\text { Control } \\
(n=15)\end{array}$ & $\begin{array}{r}2.4 \\
\pm 0.8\end{array}$ & $\begin{array}{r}62.2 \\
\pm 15.3\end{array}$ & $\begin{array}{r}0.08 \\
\pm 0.03\end{array}$ & $\begin{array}{r}120 \\
\pm 34\end{array}$ & $\begin{array}{r}11.9 \\
\pm 3.3\end{array}$ & $\begin{aligned} & 5.2^{*} \\
\pm & 1.6\end{aligned}$ & $\begin{array}{l}36.2^{*} \\
\pm 7.9\end{array}$ & $\begin{array}{r}2.0 \\
\pm 0.6\end{array}$ & $\begin{array}{r}28.2 \\
\pm 5.5\end{array}$ & $\begin{array}{r}0.31 \\
\pm 0.07\end{array}$ & $\begin{array}{r}1.18 \\
\pm 0.36\end{array}$ \\
\hline $\begin{array}{l}\text { Acyanotic } \\
(n=15)\end{array}$ & $\begin{array}{r}2.1 \\
\pm 0.4\end{array}$ & $\begin{aligned} & 59.7 \\
& \pm 11\end{aligned}$ & $\begin{array}{r}0.07 \\
\pm 0.02\end{array}$ & $\begin{array}{r}105 \\
\pm 38\end{array}$ & $\begin{array}{r}15.7 \\
\pm 4.7\end{array}$ & $\begin{aligned} & 6.6^{*} \\
\pm & 2.7\end{aligned}$ & $\begin{array}{l}37.2^{*} \\
\pm 9.3\end{array}$ & $\begin{array}{r}2.0 \\
\pm 0.7\end{array}$ & $\begin{array}{r}24.6 \\
\pm 6.2\end{array}$ & $\begin{array}{r}0.23 \\
\pm 0.08\end{array}$ & $\begin{array}{r}1.02 \\
\pm 0.22\end{array}$ \\
\hline $\begin{array}{l}\text { Cyanotic } \\
(n=15)\end{array}$ & $\begin{array}{r}3.6 \\
\pm 1.9\end{array}$ & $\begin{array}{r}57.4 \\
\pm 13.9\end{array}$ & $\begin{array}{r}0.10 \\
\pm 0.07\end{array}$ & $\begin{array}{r}125 \\
\pm 38\end{array}$ & $\begin{array}{r}12.9 \\
\pm 4.1\end{array}$ & $\begin{array}{l}5.4^{*} \\
\pm 1.9\end{array}$ & $\begin{array}{l}35.2^{*} \\
\pm 8.6\end{array}$ & $\begin{array}{r}2.1 \\
\pm 0.6\end{array}$ & $\begin{array}{r}26.8 \\
\pm 4.2\end{array}$ & $\begin{array}{r}0.32 \\
\pm 0.08\end{array}$ & $\begin{array}{r}0.80 \\
\pm 0.24\end{array}$ \\
\hline
\end{tabular}

Data are means $\pm S D$.

$* P<0.05$ compared with five min post-infusion.

tat $0.5 \mathrm{~min}$.

$\ddagger$ at $5 \mathrm{~min}$.

were no significant differences in any of the other pharmacokinetic variables.

\section{Discussion}

The $\alpha_{1}$-AGP and pharmacokinetic data for iv lidocaine in the control group in the present study are consistent with previously published values in healthy children. ${ }^{15,16}$ The serum concentration of $\alpha_{1}$-AGP is an important determinant of the free fraction of lidocaine. ${ }^{16-21}$ In this study, the percent free fraction of lidocaine varied inversely with the serum concentration of $\alpha_{1}$-AGP ( $r=0.66, P<$ 0.001 ). There was no difference in the serum concentration of $\alpha_{1}$-AGP among the three groups (Table I) and previous work has demonstrated there are no qualitative abnormalities of $\alpha_{1}$-AGP in children with CHD compared with children without CHD. ${ }^{22}$ Furthermore, previous studies have demonstrated that in both surgical and trauma patients the serum concentration of $\alpha_{1}$-AGP does not increase until six to eight hours after skin incision. ${ }^{23-25}$

We found no significant differences in the pharmacokinetic variables of lidocaine among the three groups of patients. The $t_{1} \alpha$ and $t_{1} \beta$ in this study are in agreement with the results of previous studies. ${ }^{15} \mathrm{We}$ are confident of our estimates of the distribution phase $(\varphi)$ and the volume of the central compartment $(\mathrm{Vc})$ since the distribution phase was less than $20 \mathrm{~min}$ after lidocaine (greater than three half-lives). However, the duration of this study was limited by the length of the prebypass period in children with CHD. This resulted in our restricting the period of blood sampling to $120 \mathrm{~min}$ (two terminal half-lives) in all patients. Thus, we may have underestimated the elimination half-life $\left(\mathrm{L}_{2} \beta\right)$ which in turn may result in underestimation of the $\mathrm{AUC}_{0-\infty}$ and overestimation of the total body clearance.

Our results in healthy children are in agreement with previous studies (also studied to $120 \mathrm{~min}$ ). ${ }^{15}$ The $\mathrm{t}_{2} \alpha$ of the cyanotic group was slightly, but not significantly, longer than either the control or acyanotic CHD patients. This may be attributed to the initial bypassing of the pulmonary circulation by a portion of the blood containing lidocaine, as has been described in animal studies. ${ }^{6}$ The degree of $R \rightarrow L$ shunting is variable between patients accounting for the greater variability in $4 \alpha$ as expressed by the standard deviation values.

Our results in children with $\mathrm{R} \rightarrow \mathrm{L}$ shunts differ from those obtained in a lamb model of cyanotic CHD. ${ }^{6}$ In the lambs, (with a surgically constructed $\mathrm{R} \rightarrow \mathrm{L}$ shunt) the maximum serum concentration of lidocaine was significantly greater than that in lambs with an intact cardiovascular system. The discrepancy in results between lambs and humans may be explained by differences in the doses and methods of administration of lidocaine between the two studies. In the lamb study lidocaine was administered as a rapid intravenous bolus $\left(1.0 \mathrm{mg} \cdot \mathrm{kg}^{-1}\right)$ or as a high dose by constant infusion ( $12 \mathrm{mg} \cdot \mathrm{kg}^{-1}$ over $15 \mathrm{~min}$ ) directly into the right atrium whereas in the present study lidocaine was administered iv over a $30 \mathrm{sec}$ period and into a peripheral vein. As a consequence the differences they observed may not have been apparent with our study design.

Previous work in children without $\mathrm{CHD}$ found that after the iv administration of lidocaine $\left(1.0 \mathrm{mg} \cdot \mathrm{kg}^{-1}\right)$ over 30 $\mathrm{sec}$, the peak serum concentrations did not achieve levels considered toxic in adult. ${ }^{15}$ Our data support the notion that the total serum concentration of lidocaine does not reach toxic levels. However, it is the free fraction, not total serum concentration, that determines the bioavailability of a drug and therefore determines the risk of toxicity. We found the percent free lidocaine was greatest at 0.5 min after completion of the infusion (Table II). This is most likely due to overloading of the $\alpha_{1}$-AGP binding capacity. These data suggest that toxic responses to intravenous lidocaine are more likely to occur immediately after bolus iv injection and could be obviated by 
administering acceptable doses of lidocaine by slow infusion.

In conclusion we have demonstrated that the pharmacokinetics of lidocaine $\left(1.5 \mathrm{mg} \cdot \mathrm{kg}^{-1}\right)$ following a $30-\mathrm{sec}$ infusion in children with acyanotic CHD and cyanotic CHD are not different from those in children without CHD.

\section{References}

I Tucker GT Boas RA. Pharmacokinetic aspects of intravenous regional anesthesia. Anesthesiology 1971; 34: 538-49.

2 Keenaghan $J B$, Boyes $R N$. The tissue distribution, metabolism and excretion of lidocaine in rats, guinea pigs, dogs, and man. J Pharmacol Exp Ther 1972; 180: 454-63.

3 Post C, Andersson RGG, Ryrfeldt A, Nilsson E. Transport and binding of lidocaine by lung slices and perfused lung of rats. Acta Pharmacol Toxicol 1978; 43: 156-63.

4 Post $C$, Andersson RGG, Ryrfeldt A, Nilsson E. Physiochemical modifications of lidocaine uplake in rat lung tissue. Acta Pharmacol Toxicol 1979; 44: 103-9.

5 Post $C$, Eriksdotter-Behm $K$. Dependence of lung uptake of lidocaine in vivo on blood $\mathrm{pH}$. Acta Pharmacol Toxicol 1983; 51: 136-40.

6 Bokesch PM, Castaneda AR, Ziemer G, Wilson JM. The influence of a right-to-left cardiac shunt on lidocaine pharmacokinetics. Anesthesiology 1987; 67: 739-44.

7 Wood M, Whelan E, Shay S, Wood AJJ. Acute effect of halothane on drug distribution. Anesthesiology 1989; 71: A259.

8 Mancini $G$, Carbonara $A O$, Heremans $J F$. Immunochemical quantitation of antigens by single radial immunodiffusion. Immunochemistry 1965; 2: 235-54.

9 Walberg $C B$. Lidocaine by enzyme immunoassay. J Anal Toxicol 1978; 2: 121-3.

10 Jain $S$, Johnston $A$. The measurement of lignocaine at low concentrations in plasma, a comparison of gas liquid chromatography with enzyme assay. Br J Clin Pharmacol 1979; 8: 598-9.

11 Zar JH. Biostatistical analysis. 2nd ed. Englewood Cliffs, NJ: Prentice-Hall. 1984; 185-90, 268-72, 313-4.

12 Wilkinson L. SYSTAT: The system for statistics. Evanston, Il: Systat Inc., STAT 1-7, 1987.

13 D'Argenio DZ, Schamitzky A. A program package for simulation and parameter estimation in pharmacokinetic systems. Comput Programs Biomed 1979; 9: 115-34.

14 Perrier D, Gibaldi $M$. General derivation of the equation for time to reach a certain fraction of steady state. J Pharm Sci 1982; 71 : 474-5.

15 Finholt DA, Strit JA, DiFiazio CA, Moscicki JC. Lidocaine pharmacokinetics in children during general anesthesia. Anesth Analg 1986; 65: 279-82.
16 Lerman J, Strong HA, LeDez KM, Swartz J, Rieder MJ, $B$ Brrows $F A$. Effects of age on the serum concentration of $\alpha_{1}$-acid glycoprotein and the binding of lidocaine in pediatric patients. Clin Pharmacol Ther 1989; 46: 219-25.

17 Piafsky KM, Borga O, Odar-Cederlöf I, Johansson C, Sjöqvist $F$. Increased plasma protein binding of propranolol and chlorpromazine mediated by disease-induced elevations of plasma $\alpha_{1}$ acid glycoprotein. N Engl J Med 1978; 299: 1435-9.

18 Pike E, Skuterud B, Kierulf P, Fremstad D, Abel Sayed $S M$, Lund PRM. Binding and displacement of basic, acidic and neutral drugs in normal and orosomucoiddeficient plasma. Clin Pharmacokinet 1981; 6: 367-74.

19 Routledge PA, Barchowsky A, Bjornsson TD. Kitchell BB, Shand DG. Lidocaine protein binding. Clin Pharmacol Ther 1980; 27: 347-51.

20 Shand $D G . \alpha_{1}$-acid glycoprotein and plasma lidocaine binding. Clin Pharmacokinet 1984; 9 (Suppl I): 27-31.

21 McNamara PJ, Slaughter RL, Pieper JA, Wyman MG, Lalka $D$. Factors influencing serum protein binding of lidocaine in humans. Anesth Analg 1981; 60: 395-400.

22 Burrows FA, Lerman J, LeDez KM, Strong HA. Alpha,acid glycoprotein and the binding of lidocaine in children with congenital heart disease. Can J Anaesth 1990; 37: 883-88.

23 Edwards DJ, Lalka D, Cerra F, Slaughter RL. Alpha,-acid glycoprotein concentration and protein binding in trauma. Clin Pharmacol Ther 1982; 31: 62-7.

24 Colley CM, Fleck A, Goode AW, Muller BR, Myers $M A$. Early time course of acute phase protein response in man. J Clin Pathol 1983; 36: 203-7.

25 Aronsen $K-F$, Ekelund $G$, Kindmark $C$-O et al. Sequential changes of plasma proteins after surgical trauma. Scand J Clin Lab Invest 1972; 29: 127-36. 